\title{
INFLUENCE OF INOCULATION METHODS AND THE AMOUNT OF AN ADDED INOCULANT ON THE MECHANICAL PROPERTIES OF DUCTILE IRON
}

\author{
VPLIV METOD MODIFIKACIJE IN KOLIČINE DODANEGA \\ MODIFIKATORJA NA MEHANSKE LASTNOSTI DUKTILNEGA \\ ŽELEZA
}

\author{
Hasan Avdušinović ${ }^{1}$, Almaida Gigović-Gekić ${ }^{1}$, Diana Ćubela ${ }^{1}$, \\ Raza Sunulahpašić ${ }^{1}$, Nermin Mujezinović ${ }^{2}$ \\ ${ }^{1}$ University of Zenica, Faculty of Metallurgy and Materials Science, Travnička cesta 1, 72000 Zenica, Bosnia and Herzegovina \\ ${ }^{2}$ CIMOS TMD CASTING, d. o. o., Zenica, Radna zona Zenica-1 bb, 72000 Zenica, Bosnia and Herzegovina \\ hasan.avdusinovic@famm.unze.ba \\ Prejem rokopisa - received: 2014-09-30; sprejem za objavo - accepted for publication: 2014-10-13
}

doi: $10.17222 / \mathrm{mit} .2014 .248$

In most cases an addition of inoculants to molten cast iron is advisable and even necessary to produce good-quality castings The mechanical properties and machinability of cast iron with nodular graphite greatly depend on the formation of graphite and the matrix microstructure and both are significantly influenced by the inoculation treatment. The mechanism of inoculation, the influence of the inoculation method and the amount of added inoculants are presented.

Keywords: ductile iron, inoculation, microstructure, graphite, metallic matrix

V večini primerov je dodatek modifikatorjev staljenemu livnemu železu priporočljiv in celo potreben za izdelavo dobrih ulitkov. Mehanske lastnosti in obdelovalnost litega železa z nodularnim grafitom so močno odvisne od oblike grafita in od mikrostrukture osnove, na oboje pa močno vpliva obdelava z modifikatorji. Predstavljen je mehanizem modifikacije, vpliv metode modifikacije in vpliv količine dodanega modifikatorja.

Ključne besede: duktilno železo, inokulacija, mikrostruktura, grafit, kovinska osnova

\section{INTRODUCTION}

Inoculants are the materials added to molten cast iron, modifying the microstructure and, thereby, changing the physical and mechanical properties to a degree not explained on the basis of the change in the composition. Inoculation is a phase of the technological process of producing ductile iron that controls and improves the microstructure and mechanical properties of castings. Through inoculation, graphite nucleation and eutectic undercooling of the melt can be controlled, which is crucial for achieving the required service properties of the castings. ${ }^{1-3}$

The inoculant most commonly used in foundries is a ferrosilicon alloy with precisely defined contents of $\mathrm{Ca}$, $\mathrm{Ba}, \mathrm{Sr}, \mathrm{Zr}, \mathrm{Al}$ and rare-earth elements. The benefits of inoculations are: an improved machinability, increased strength and ductility, reduced hardness and fracture sensitivity, a more homogenous microstructure, a reduced tendency for solidification shrinkage, etc.

During modularizing, numerous inclusions with a sulfide core and an outer shell containing complex magnesium silicates are formed. Such micro-inclusions do not provide an effective nucleation for graphite because the crystal lattice structure of magnesium silicates does not match sufficiently with the lattice structure of gra- phite. After the inoculation with a ferrosilicon alloy containing $\mathrm{Ca}, \mathrm{Ba}$ or $\mathrm{Sr}$, the surfaces of the micro-inclusions are modified and other complex $\mathrm{Ca}, \mathrm{Sr}$, or $\mathrm{Ba}$ silicate layers are obtained. Such silicates have the same hexagonal crystal lattice as graphite and act as effective nucleation sites for graphite nodules to grow during solidification. ${ }^{4}$

The required rate of adding inoculants to a liquid depends very much on the place and time of their inoculation.

\section{EXPERIMENTAL PROCEDURE}

In the investigations of the response of ductile-iron test melts to different amounts of added inoculants and different inoculation methods, three types of the inoculation method were applied: the ladle inoculation, the in-stream inoculation and the in-mold inoculation. The partner foundry in this research project was "Cimos TMD Casting" in Zenica.

In the first project step, 15 melts were prepared. Full lists of the chemical compositions, the amounts of added inoculants and the places of the inoculant introduction are included in Table 1. High-purity FeSi with additions of $\mathrm{Al}, \mathrm{Ca}$, and $\mathrm{Sr}$ was used for the inoculation. The test 
H. AVDUŠINOVIĆ et al.: INFLUENCE OF INOCULATION METHODS AND THE AMOUNT OF AN ADDED INOCULANT ...

Table 1: Chemical compositions of the experimental melts, places of the inoculation and added amounts of the inoculants (first step of the project)

Tabela 1: Kemijska sestava eksperimentalnih talin, mesto dodajanja modifikatorja in količina dodanega modifikatorja (prva stopnja projekta)

\begin{tabular}{|c|c|c|c|c|c|c|c|c|c|c|c|c|}
\hline \multirow[t]{2}{*}{ No. } & \multicolumn{8}{|c|}{ Chemical composition $(\%)$} & \multicolumn{3}{|c|}{ Inoculant $(\%)$} & \multirow{2}{*}{$\begin{array}{c}\text { Temp. } \\
{ }^{\circ} \mathrm{C}\end{array}$} \\
\hline & $\mathrm{C}$ & $\mathrm{Si}$ & $\mathrm{Mn}$ & $\mathrm{P}$ & $\mathrm{S}$ & $\mathrm{Cr}$ & $\mathrm{Cu}$ & $\mathrm{Mg}$ & stream & mold & ladle & \\
\hline 1 & 3.52 & 2.17 & 0.428 & 0.016 & 0.006 & 0.086 & 0.314 & 0.043 & 0 & 0 & 0 & 1388 \\
\hline 2 & 3.51 & 2.20 & 0.433 & 0.016 & 0.006 & 0.090 & 0.314 & 0.040 & 0 & 0.05 & 0 & 1392 \\
\hline 3 & 3.49 & 2.06 & 0.401 & 0.015 & 0.006 & 0.089 & 0.332 & 0.032 & 0 & 0.15 & 0 & 1402 \\
\hline 4 & 3.58 & 2.15 & 0.403 & 0.014 & 0.005 & 0.076 & 0.346 & 0.043 & 0 & 0.20 & 0 & 1407 \\
\hline 5 & 3.56 & 2.09 & 0.482 & 0.011 & 0.003 & 0.111 & 0.340 & 0.040 & 0.05 & 0.05 & 0 & 1395 \\
\hline 6 & 3.44 & 2.11 & 0.485 & 0.012 & 0.003 & 0.095 & 0.356 & 0.047 & 0.05 & 0.10 & 0 & 1410 \\
\hline 7 & 3.60 & 2.14 & 0.345 & 0.016 & 0.006 & 0.054 & 0.080 & 0.053 & 0.10 & 0 & 0 & 1380 \\
\hline 8 & 3.54 & 2.10 & 0.337 & 0.017 & 0.009 & 0.071 & 0.090 & 0.055 & 0.05 & 0 & 0 & 1380 \\
\hline 9 & 3.52 & 2.15 & 0.362 & 0.014 & 0.007 & 0.064 & 0.091 & 0.045 & 0.15 & 0 & 0 & 1390 \\
\hline 10 & 3.56 & 2.11 & 0.398 & 0.017 & 0.008 & 0.068 & 0.316 & 0.047 & 0.10 & 0.05 & 0 & 1400 \\
\hline 11 & 3.62 & 2.45 & 0.353 & 0.017 & 0.009 & 0.049 & 0.119 & 0.065 & 0.20 & 0 & 0 & 1387 \\
\hline 12 & 3.65 & 2.11 & 0.392 & 0.019 & 0.012 & 0.054 & 0.149 & 0.079 & 0.15 & 0.05 & 0 & 1405 \\
\hline 13 & 3.62 & 2.12 & 0.382 & 0.019 & 0.011 & 0.054 & 0.144 & 0.060 & 0 & 0.20 & 0 & 1390 \\
\hline 14 & 3.61 & 2.11 & 0.357 & 0.018 & 0.009 & 0.037 & 0.187 & 0.048 & 0 & 0 & 0.05 & 1398 \\
\hline 15 & 3.64 & 2.14 & 0.384 & 0.016 & 0.011 & 0.084 & 0.212 & 0.052 & 0 & 0 & 0.20 & 1402 \\
\hline
\end{tabular}

Table 2: Range of the chemical compositions of the test melts (second step of the project)

Tabela 2: Obseg kemijskih sestav preizkusnih talin (druga stopnja projekta)

\begin{tabular}{|c|c|c|c|c|c|c|}
\hline Composition & $\mathrm{C}$ & $\mathrm{Si}$ & $\mathrm{Mn}$ & $\mathrm{S}$ & $\mathrm{P}$ \\
\hline$w / \%$ & $3.4-3.6$ & $2.1-2.3$ & $0.2-0.4$ & $0.003-0.012$ & $0.01-0.02$ & $0.003-0.055$ \\
\hline
\end{tabular}

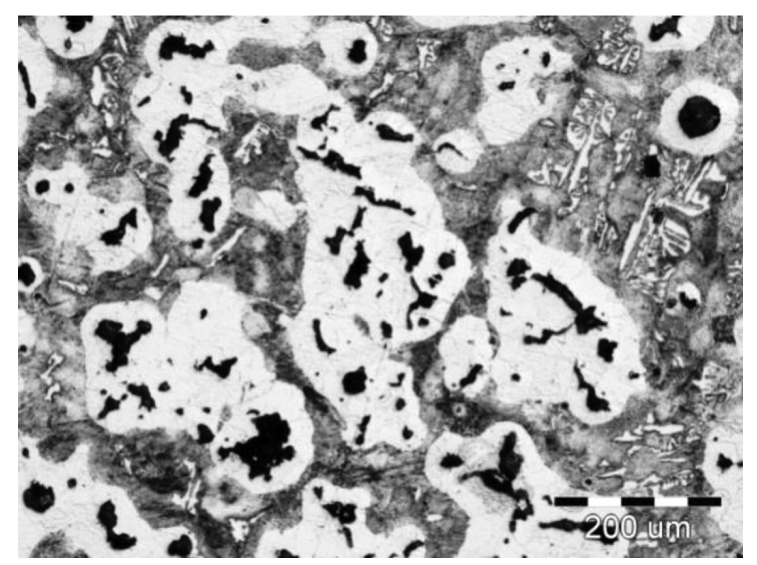

Figure 1: Ladle inoculation, Nital etched

Slika 1: Modifikacija v ponvi, jedkano v nitalu

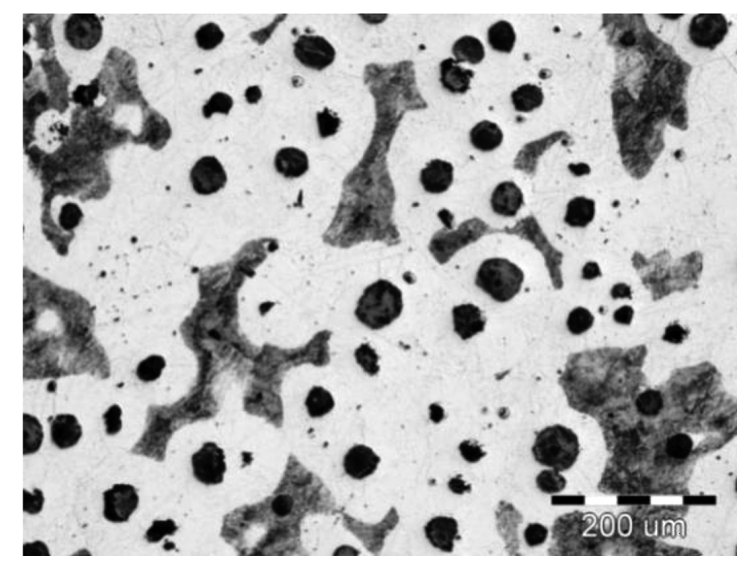

Figure 2: In-stream inoculation, Nital etched

Slika 2: Modifikacija v curek, jedkano v nitalu iron melts were obtained using an induction furnace and casting iron into a green-sand mold. After the casts were cooled down and cleaned, samples for the mechanicalproperty examination were prepared. ${ }^{1}$

The testing of the mechanical properties was performed according to BAS EN 100002:2002 relating to tensile testing and BAS EN 6507-1/2007 relating to hardness testing of fractured tensile-test bars.

Based on the summary of the results of testing the casting properties, conclusions about the optimum amounts of the added inoculants needed for obtaining the required values of the mechanical properties, were drawn.

Casting procedures involving the exact amounts of the added inoculants required for three different methods

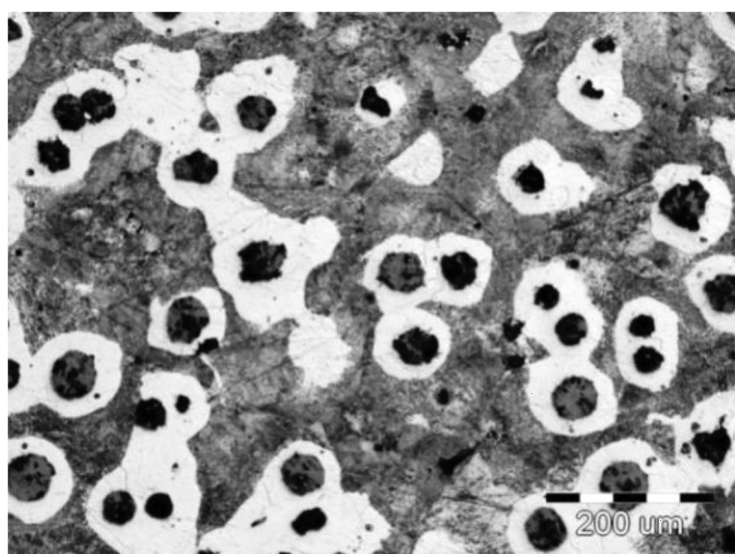

Figure 3: In-mold inoculation, Nital etched

Slika 3: Modifikacija v kokili, jedkano v nitalu 


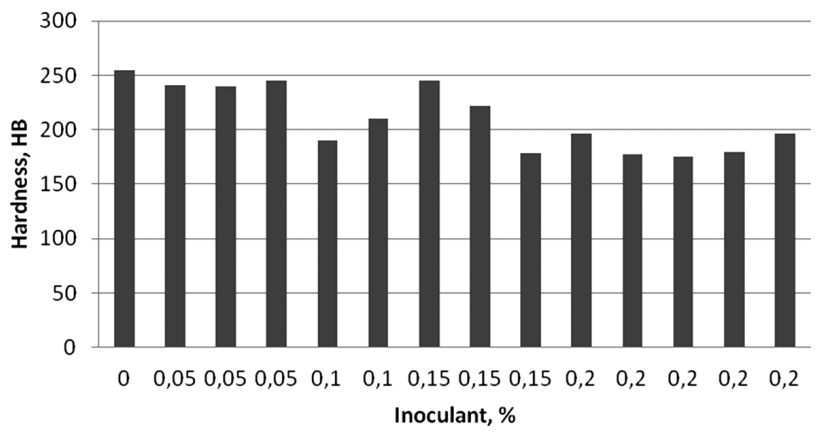

Figure 4: Hardness values of the tested samples (first step of the project)

Slika 4: Trdota preizkusnih vzorcev (prva stopnja projekta)

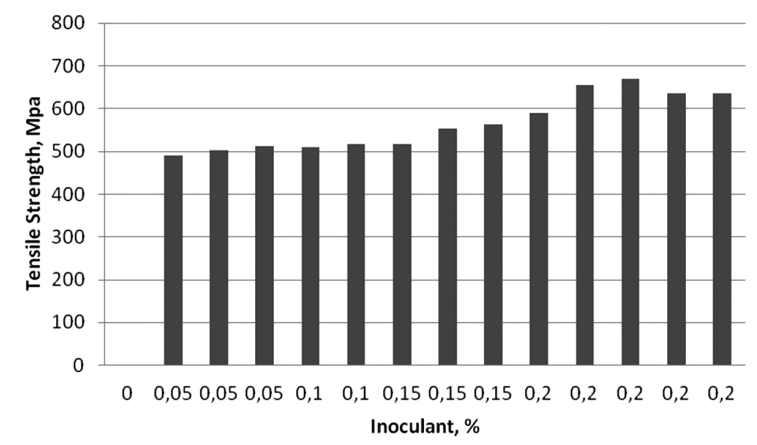

Figure 5: Tensile-strength values of the tested samples (first step of the project)

Slika 5: Natezna trdnost preizkusnih vzorcev (prva stopnja projekta)

Table 3: Average values and standard deviations of the hardness and tensile strength (second step of the project)

Tabela 3: Povprečne vrednosti in standardna deviacija trdote in natezne trdnosti (druga stopnja projekta)

\begin{tabular}{|c|c|c|c|c|c|c|}
\hline & \multicolumn{3}{|c|}{ Hardness (HB) } & \multicolumn{2}{c|}{ Tensile strength (MPa) } \\
\hline $\begin{array}{c}\text { Inoculatio } \\
\text { n method }\end{array}$ & In mold & $\begin{array}{c}\text { In } \\
\text { stream }\end{array}$ & Ladle & In mold & $\begin{array}{c}\text { In } \\
\text { stream }\end{array}$ & Ladle \\
\hline Average & 212.15 & 203.8 & 205.3 & 564.65 & 546.3 & 474.95 \\
\hline $\begin{array}{c}\text { St. } \\
\text { deviation }\end{array}$ & 7.86 & 6.88 & 27.02 & 29.1 & 9.41 & 33.61 \\
\hline
\end{tabular}

of inoculation were conducted in the second step to find the most suitable casting technology in the partner foundry. A total of 60 melts were prepared in the second step of the project and the average melt chemical composition is presented in Table 2 .

\section{RESULTS AND DISCUSSION}

Figures 1 to 3 show the microstructures of the samples taken from the melts (castings) inoculated with different methods; the tensile strengths and hardness values are presented in Figures $\mathbf{4}$ and $\mathbf{5}$.

The required hardness was in the range of 180-220 $\mathrm{HB}$ and the tensile strength was in the range of 500-550 $\mathrm{MPa}$. According to the results in Figures $\mathbf{1}$ and $\mathbf{2}$, the best result was observed with the samples with $0.1 \%$ of the inoculants. In the second project step we used 20

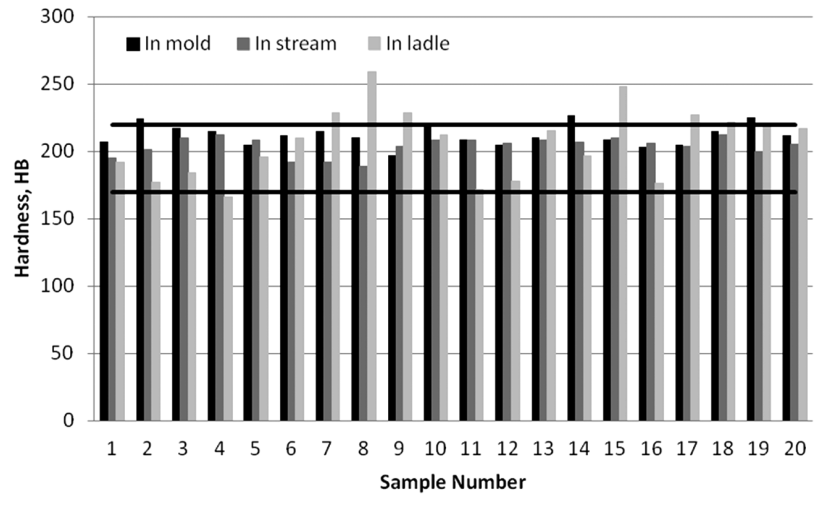

Figure 6: Hardnes values of the tested samples (second step of the project); black horizontal bars - targeted values

Slika 6: Trdota preizkusnih vzorcev (druga stopnja projekta); črne vodoravne črte - ciljne vrednosti

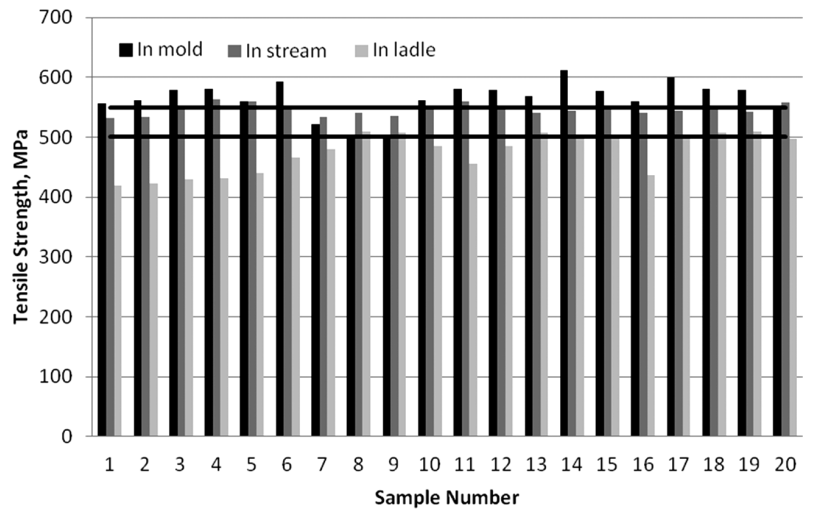

Figure 7: Tensile-strength values of the tested samples (second step of the project); black horizontal bars - targeted values

Slika 7: Natezna trdnost preizkusnih vzorcev (druga stopnja projekta); črne vodoravne črte - ciljne vrednosti

melts for each inoculation method, i.e., 60 melts were treated with $0.1 \%$ of the added inoculants. The mechanical properties are shown in Figures 6 and 7 and in Table 3.

\section{CONCLUSIONS}

Experimental materials with quite satisfactory characteristics were prepared with vacuum induction melting. The results obtained in the first project step showed that with $0.1 \%$ of the inoculant the targeted hardness and tensile strength for the given ductile iron were achieved.

In the second project step it was found that the in-stream inoculation ensured the best result as almost $100 \%$ of all the samples achieved the targeted values for the hardness and tensile strength and the standard deviation was the smallest.

\section{Acknowledgment}

The authors would like to thank the Federal Ministry of Education and Science of the Federation of Bosnia 
H. AVDUŠINOVIĆ et al.: INFLUENCE OF INOCULATION METHODS AND THE AMOUNT OF AN ADDED INOCULANT ...

and Herzegovina and Foundry "CIMOS TMD CASTING" in Zenica for their financial aid and cooperation during the implementation of the research project.

\section{REFERENCES}

${ }^{1}$ H. Bornstein et al., Cast Metals Handbook, American Foundrymen's Society, Des Plaines, Illinois, USA 1957, 31

${ }^{2}$ E. Fras, M. Gorny, Inoculation Effects of Cast Iron, Archives of Foundry Engineering, 12 (2012) 4, 39-46

${ }^{3}$ J. N. Harvey, G. A. Noble, Inoculation of Cast Irons - An Overview, $55^{\text {th }}$ Indian Foundry Congress, India, 2007, 343-360

${ }^{4}$ T. Skaland, A New Approach to Ductile Iron Inoculation, American Foundry Society, Schaumburg, Illinois, USA 2001 